\title{
HORTI BANK: THE CONCEPT OF AGRICULTURAL FINANCING THROUGH FARMER GROUP SYNERGY TO INCREASE THE WELFARE OF HORTICULTURAL FARMERS AFFECTED BY COVID-19 IN EAST JAVA
}

\author{
Ahmad Burhanudin*1 \\ Adinda Permatasari² \\ Safira Ummah ${ }^{3}$
}

\begin{abstract}
${ }^{1}$ Program Studi Penyuluhan Pertanian, Fakultas Pertanian, Universitas Jember, Indonesia
2,3Program Studi Agribisnis, Fakultas Pertanian, Universitas Jember, Indonesia
\end{abstract}

*Korespondensi: Ahmad Burhanudin e-mail: ahmadburhanudin722@gmail.com tively large number of cases. The agricultural sector is present as a resilient sector that cansurvive the COVID-19 pandemic which can contribute to supporting the economic growth rate of EastJava. The agricultural sector consists of several sub-sectors, one of which is the horticultural cropsub-sector which has high potential. There are many obstacles experienced by horticultural farmers intheir farming. The COVID-19 pandemic has hampered the distribution of horticultural products and at the same time resulted in a drop in the price of these products in the market.The purpose of this study is to determine the problems experienced by horticulturalfarmers in East Java Province and to form an institutional model as a solution to the problem toimprove the welfare of horticultural farmers in East Java Province through increasing NTP (FarmerExchange Rate). Analytical descriptive method, case study method and literature study were used inthis research. The results showed that (1) the problems experienced by farmers were (a) horticulturalfarmers generally have a relatively small capacity to provide capital; (b) Sales of horticultural cropsare only made to middlemen; (c) Low accessibility to local financing institutions; (d) Agriculturalfinancing credit system that is too burdensome for farmers; (e) There is a gap between farmers andfinancial institutions; (f) Credit by formal institutions is prioritized in the non-agricultural sector; (2)The existence of the "HortiBank" institution whichis implementedwillhelp in overcomingtheproblems of horticultural farmers in East Java Province by providing facilities in the form of capitalloans withthe conceptof investment, managing finances, and providing access to insurance forhorticultural farmers in East Java Province; (3) The simulation results show that the existence of aHorti Bank can increase the exchange rate of farmers so that it is expected to reduce poverty in East Java.

Keywords: Regional Income, Monetary Policy, Credit, Money Supply

\section{ABSTRAK}

Penyebaran virus covid-19 secara masif berdampak terhadap ekonomi Jawa Timur. Tujuan penelitian untuk 1) memprediksi perkembangan kasus Covid-19 di Jawa Timur; 2) melakukan simulasi kebijakan makro (moneter) efektif guna meningkatkan perekonomian Jawa Timur saat pandemik covid-19. Penelitian ini menggunakan model ekonometrika dengan sistem persamaan simultan menggunakan metode Two Stage Least Square (2SLS). Hasil penelitian menunjukkan bahwa peningkatan pemberian kredit konsumsi dan pertanian

East Java Economic Journal, p-ISSN: 2597-8780, DOI: 10.53572/ejavec.v4i1.34, Open access under a Creative Commons Attribution- 4.0 
di Jawa Timur dapat dikatakan cukup efektif untuk meningkatkan perekonomian di Jawa Timur. Peningkatan jumlah uang beredar di Jawa Timur juga efektif dalam meningkatkan perekonomian Jawa Timur, namun memberikan dampak yang negatif terhadap PDRB pertanian dan inflasi di Jawa Timur. Kebijakan yang paling efektif dalam rangka mengurangi dampak ekonomi dari Covid-19 adalah kebijakan peningkatan pemberian kredit kepada masyarakat berupa kredit konsumsi atau kredit pertanian sebesar 15\%.

Kata kunci: Kebijakan Moneter, Kredit, Uang, Pendapatan Daerah

JEL: G2, G5, Q1

\section{Pendahuluan}

Sejak awal Januari 2020, Corona Virus Diseases 2019 (COVID-19) menjadi permasalahan kesehatan yang dialami oleh seluruh dunia. Menurut World Health Organization (WHO) Coronaviruses (Cov) adalah virus yang menginfeksi system pernapasan. Virus ini pertama kali ditemukan menyebar pada puluhan orang di kota Wuhan hingga pada akhirnya menyebar ke berbagai Negara termasuk Indonesia. Berdasarkan data World Health Organization per 29 September 2020 setidaknya terdapat 216 negara yang telah terpapar virusdan dengan jumlah pasien yang positif terjangkit COVID-19 mencapai 33.206.004 jiwa. Peningkatan jumlah kasus positif COVID-19 disebabkan oleh adanya penyebaran COVID-19 yang terjadi melalui droplet dan kontak dengan droplet. Menurut Dr. Eric Topol, seorang ahli jantung dan direktur Scripps Reserach TransItational Institute di La Jolla California mengungkapkan bahwa dampak dari COVID-19 tidak hanya pada pernapasan biasa, melainkan juga berdampak pada pangkreas, hati, otak, ginjal, dan organ-organ penting lainnya (Bramasta, 2020). Penyebaran COVID-19 di Indonesia terbilang cukup cepat. Berdasarkan data Gugus Tugas Percepatan Penanganan COVID-19 yang dilansir dari laman covid19.go.id per tanggal 29 September 2020 tercatat sebanyak 282.724 pasien positif COVID-19, dengan 20.437 pasien dinyatakan sembuh, dan 10.601 pasien meninggal dunia. Provinsi DKI Jakarta menempati urutan pertama dalam jumlah kasus terinfeksi COVID-19 dengan persentase 25,6\% (71.339 kasus), disusul Provinsi Jawa Timur 15,5\% (43.174 kasus), dan Jawa Tengah 7,7\% (21.937 kasus). Sejak bulan April 2020, pemerintah telah memberlakukan kebijakan Pembatasan Sosial Berskala Besar (PSBB) sebagai upaya untuk meminimalisir rantai penyebaran COVID-19 diberbagai wilayah yang rentan terjadi penambahan kasus penyebaran COVID-19 dalam skala besar.

Kebijakan PSBB disisi lain juga berimbas pada penurunan pertumbuhan perekonomian nasional. Beberapa sektor ekonomi yang bergantung pada interaksi sosial seperti pariwisata, industri, dan perdagangan mengalami penurunan yang kemudian berpengaruh terhadap kinerja UMKM, sektor rumah tangga, dan angka kemiskinan. PSBB mengakibatkan terhambatnya sektor pariwisata karena adanya kebijakan penutupan tempat wisata, hilangnya sumber mata pencaharian bagi para pekerja (banyak terjadi PHK), perubahan pola konsumsi masyarakat, serta terganggunya transportasi sebagai akibat pembatasan pergerakan yang berimbas pada penurunan pertumbuhan (Nugroho dkk., 2015). Pertumbuhan ekonomi Indonesia pada triwulan I-2020 terhadap triwulan sebelumnya (triwulan IV-2019) mengalami konstraksi yang mencapai 2,41\% (qtq), sementara capaian pertumbuhan ekonomi triwulan I-2020 terhadap triwulan I-2019 hanya 2,97\% (yoy) padahal pada triwulan I-2019 mampu mencapai 5,07\% (yoy), hal ini menunjukkan terjadinya pelemahan ekonomi yang cukup signifikan pada periode berlangsungnya pandemi COVID-19 (BPS, 2020)

Pelemahan ekonomi juga dialami oleh Provinsi dengan jumlah kasus relatif besar seperti Jawa Timur. Pertumbuhan ekonomi Jawa Timur di masa pandemi COVID-19 pada triwulan I 2020 sebesar 3,02\% atau mengalami penurunan sebesar 2,5\% dari triwulan IV 2019. Sementara pada triwulan II perekonomian Jawa Timur justru terkontraksi 5,90\%. Ekspor migas dan non-migas Jawa Timur pada April 2020 juga mengalami penurunan sejumlah 30,87\% atau 
1,37 miliar rupiah jika dibandingkan dengan bulan sebelumnya yang mencapai 1,98 miliar rupiah. Apabila dibandingkan dengan Maret 2019, nilai ekspor di Jawa Timur juga mengalami penurunan sebesar $12,85 \%$. Adanya penurunan nilai ekspor tersebut disebabkan oleh penurunan kinerja ekspor baik pada sektor migas maupun nonmigas, hal tersebut dapat terjadi sebagai dampak adanya pandemi COVID-19 ini (BPS Jatim, 2020)

Pandemi COVID-19 yang mampu menyebabkan pelemahan ekonomi dapat ditangani dengan penguatan sektor ekonomi yang mampu bertahan di kondisi saat ini. Kebijakan PSBB yang berujung pada penerapan pola hidup new normal oleh masyarakat menuntut sektor perekomonian dasar (base economic) seperti sektor pertanian sebagai stabilitas perekonomian, utamanya di daerah yang terdampak COVID-19 dengan skala besar seperti Jawa Timur. Sektor pertanian berperan penting dalam perwujudan ketahanan pangan mandiri selama pandemi, selain itu juga berperan sebagai sumber mata pencaharian utama maupun sampingan bagi pekerja terdampak COVID-19. Pertumbuhanlapangan usaha sektor pertanian di Jawa Timur pada triwulan II-2020 terhadap triwulan I-2020 sebesar 16\% (qtq), angka ini mampu mengalahkan sektor lain yang justru mengalami penurunan, seperti sektor pertambangan dan penggalian (-4\%), industri pengolahan (-6\%), konstruksi $(-7 \%)$ atau bahkan transportasi dan pergudangan (-29\%), (BPS, 2019). Data tersebut telah menguatkan bahwa sektor pertanian mampu menjadi senjata tangguh untuk kembali bangkit dari kondisi ekonomi yang kian terpuruk. Resiliensi sektor pertanian dalam upaya pemulihan perekonomian Jawa Timur harus ditunjang melalui integrasi antar sektor maupun antar sub sektor pertanian itu sendiri.

Sub sektor pertanian seperti tanaman pangan, tanaman hortikultura, tanaman perkebunan, perikanan, maupun peternakan berperan dalam menunjang sektor pertanian secara terpadu. Salah satu dari sub sektor tersebut, yaitu sub sektor tanaman hortikultura dapat berkontribusi dalam menunjang laju pertumbuhan ekonomi Jawa Timur jika dilihat dari salah satu indikatornya yaitu kenaikan harga barang dan jasa (inflasi). Sub sektor tanaman hortikultura berpotensi menjadi sumber pendapatan petani, perdagangan, dan sekaligus penyerapan tenaga kerja. Sub sektor tanaman hortikultura telah menyumbang $9 \%$ dari total sumbangsih sektor pertanian terhadap PDRB Jawa Timur Menurut Lapangan Usaha Tahun 2019, meskipun tergolong kecil namun kontribusinya dari tahun ke tahun cenderung stabil dan meningkat (BPS Jatim, 2020). Ketersediaan lahan dan produktivitas lahanhortikultura harus ditingkatkan secara kontinyu guna mengoptimalkan peranan sub sektor hortikultura terhadap peningkatan produksi pertanian secara keseluruhan.

Peningkatan produksi pertanian utamanya komoditas hortikultura pada kondisi new normal masih menemui banyak kendala dan hambatan. COVID-19 beserta implementasi kebijakan terkait penanganannya juga berimbas pada produksi, rantai pasok (supply chain), dan konsumsi masyarakat khususnya komoditas hortikultura. Akibatnya terjadi penurunan konsumsi rumah tangga sebagai indikasi penurunan kesejahteraan masyarakat yang menyebabkan terjadinya kelebihan produksi dibandingkan dengan konsumsi sehingga berimplikasi terhadap terjadinya kelebihan penawaran (Nugroho dkk., 2015). Penurunan konsumsi rumah tangga dapat berpengaruh terhadap penurunan permintaan pasar, sedangkan asumsi masyarakat terhadap pertanian sebagai sumber pendapatan yang mampu bertahan di masa pandemi dapat menyebabkan peningkatan penawaran. Ketidakselarasan antara permintaan dan penawaran komoditas pertanian dapat menyebabkan fluktuasi harga pangan khususnya produk hortikultura (Sujai, 2016). Harga produk hortikultura mengalami penurunan secara drastis, hal ini tentu akan berdampak pada penurunan pendapatan petani dan penurunan Nilai Tukar Petani (NTP) hortikultura. Apabila kondisi tersebut terjadi secara berkelanjutan tentunya dapat meningkatkan angka kemiskinan di masyarakat. Kendala lain yang harus dihadapi oleh petani hortikultura ialah kurangnya peran kelembagaan yang terkait dengan bidang 
pertanian, padahal upaya revitalisasi organisasi dan peran kelembagaan petani dapat menjadi strategi dalam memperkuat posisi tawar petani (Saragih dkk., 2016).

Kelembagaan pada sub sektor hortikultura biasanya terkendala dari faktor pembiayaan dan asuransi. Pembiayaan terbesar pada komoditi sayur-mayur biasanya berkaitan dengan pengadaan sarana produksi, sedangkan pada komoditi buah-buahan terletak pada pembiayaan kegiatan pemeliharaan. Penyediaan sarana produksi bagi petani hortikultura sebenarnya sudah dapat dipenuhi oleh kios penyedia kebutuhan sarana produks, namun biasanya kendala yang dialami petani berkaitan dengan minimnya daya dukung pembiayaan untuk penggunaan teknologi usahatani. Minimnya pembiayaan biasanya disebabkan faktor risiko pembiayaan yang tinggi, ketatnya persyaratan, serta kompetensi kelembagaan yang masih terbatas (Sunartomo, 2014). Model kelembagaan yang biasanya diterapkan berupa pasar pembiayaan formal dan informal. Pembiayaan formal biasanya melalui bank- bank pemerintah maupun swasta dengan menggunakan tingkat bunga komersial yang mengikuti mekanisme pasar. Pembiayaan informal biasanya melalui pedagang input maupun pedagang output pertanian dengan menggunakan sistem hutang. Sayangnya model kelembagaan tersebut masih belum optimal dalam mendukung usahatani hortikutultura. Aturan main yang ada pada skim pembiayaan formal masih bersifat rigid, sehingga masyarakat pedesaan khususnya petani kesulitan dalam mengakses sumber pembiayaan model ini. Sementara pembiayaan informal yang biasanya melibatkan tengkulak juga dapat merugikan petani, hal ini didukung dari kurangnya informasi pasar yang diterimapetani sehingga bisa saja biaya yang dibebankan oleh tengkulak kepada petani terlalu besar sehingga minimnya pembiayaan pada usahatani hortikultura masih tetap terjadi (Pratiwi dkk., 2019).

Minimnya kelembagaan yang menyediakan pembiayaan usahatani hortikultura di samping murahnya harga komoditas hortikultura menyebabkan petani hortikultura benar-benar merugi di masa pandemi ini. Di wilayah Jawa Timur tepatnya didaerah Malang, harga komoditi sayur seperti cabai dan tomat turun drastis (Aminudin, 2020). Sedangkan di wilayah Jember, anjloknya harga komoditi sayur dan buah meliputi kubis, cabai, dan tomat (Kompas, 2020). Anjloknya harga komoditi buah maupun sayur telah mengakibatkan petani hortikultura di daerah tersebut semakin terpuruk. Penurunan harga komoditi selama pandemi menyebabkan sulitnya petani untuk mendapatkan jaminan pembiayaan, pelemahan permintaan pasar dapat pula menyebabkan petani sebagai debitur mengalami pemutusan hubungan kerja karena dirasa tidak dapat mengembalikan modal yang dipinjamkan (Sinaga dan Tarigan, 2020). Permasalahan tersebut tentu perlu solusi berupa kelembagaan yang berfungsi sebagai fasilitator yangdapat membantu pelaku sub sektor hortikultura dalam mengatasi masalah pembiayaan usahatani ditengah pandemi COVID-19 guna mengurangi tingkat kemiskinan khususnya di wilayah pedesaan Provinsi Jawa Timur. Penelitian sebelumnya yaitu "revitalisasi implementasi pemberdayaan kelembagaan pertanian berkesinambungan mendukung pencapaian daya saing produk olahan" menganalisis salah satu pertimbangan perlunya kelembagaan pertanian yang berkaitan dengan nilai tambah, dengan skema revitalisasi kelembagaan yang menitikberatkan pada kelembagaan komunitas, publik, dan pemasaran (Elizabeth, 2019). Sementara penelitian ini akan lebih dikaji bagaimana peranan kelembagaan pembiayaan hortikultura jika dikaitkan dengan kondisi pandemi. Dampak pandemi terhadap petani hotikultura dapat dilihat dari analisis NTP sebelum dan sesudah pandemi.

Pentingnya kelembagaan petani diakui dalam pembangunan pertanian baik di negara industri maupun negara sedang berkembang seperti Indonesia. Kelembagaan petani diharapkan mampu membantu petani keluar dari persoalan kesenjangan ekonomi petani (Anantanyu, 2011). Berdasarkan latar belakang di atas, penelitian ini bertujuan untuk: (1) Mengidentifikasi permasalahan pembiayaan petani hortikultura pada masa pandemi COVID-19 
di wilayah Provinsi Jawa Timur, (2) mengidentifikasi sistem kelembagaan yang tepat, sebagai solusi permasalahan pembiayaan petanihortikultura pada masa pandemi COVID-19 di wilayah Provinsi Jawa Timur, (3) menganalisis dampakkelembagaan tersebut terhadap NTP dan tingkat kemiskinan di wilayah pedesaan Provinsi JawaTimur. Penelitian ini diharapkan mampu memberikan manfaat kepada para petani, pemerintah maupun lembaga perbankan khususnya dalam memberikan informasi dan penentuan kebijakan mengenai strategi akselerasi pertumbuhan ekonomi Jawa Timur melalui sub sektor hortikultura yang secara nyata telah berkontribusi terhadap laju pertumbuhan ekonomi Provinsi Jawa Timur.

\section{Tinjauan Pustaka}

\section{Pertumbuhan Ekonomi}

Menurut Todaro dan Smith (2005), pertumbuhan ekonomi sebagai sebuah proses peningkatan output dari waktu ke waktu menjadi indikator penting untuk mengukur sebuah keberhasilan pembangunan suatu negara. Pertumbuhan ekonomi dengan pembangunan ekonomi merupakan dua halyang berbeda tapi tidak dapat terpisah satu sama lain, sebab pembangunan ekonomi akan bergantung pada pertumbuhan ekonomi sebagai indikator kemajuan. Melalui pertumbuhan ekonomi maka akan diketahuihasil tambahan pendapatan masyarakat pada periode tertentu. Berdasarkan hal tersebut, maka dapat dikatakan pertumbuhan ekonomi bersifat kuantitatif dan bias diukur dengan menggunakan data Produk Domestik Bruto (PDB) yang dapat mencerminkan nilai uang. Menurut Aspiansyah dan Damayanti (2019), pertumbuhan ekonomi di Indonesia dipengaruhi oleh faktor-faktor dari dalam maupun dari luar wilayah yang tidak dapat diabaikan, sebab pertumbuhan ekonomi akan berpengaruh pada pendapatan nasional. Pertumbuhan ekonomi yang mempengaruhi pendapatan nasional dapat terjadi karena adanya peningkatan kegiatan ekonomi masyarakat yakni peningkatan jumlah produksi barang dan jasa. Output pada semua barang dan jasa yang diproduksi akan digunakan dalam perhitungan Produk Domestik Bruto (PDB), sehingga perhitungan tersebut tidak bisa dilakukan setiap saat dan umumnya dilakukan setiap tiga bulan dan tahunan.

Produk Domestik Bruto (PDB) digunakan untuk melihat pertumbuhan ekonomi tingkat nasional, sedangkan pertumbuhan ekonomi tingkat regional dapat diketahui melalui Produk Domestik Regional Bruto (PDRB) yang merupakan indikator ekonomi. Masyarakat pada suatu daerah tertentu yang melakukan transaksi akan menjadi sumber uatama dalam Pendapatan Domestik Regional Bruto (PDRB). Pendapatan Domestik Regional Bruto (PDRB) merupakan jumlah keseluruhan nilai tambah barang dan jasa yang dihasilkan oleh seluruh kegiatan perekonomian di daerah tertentu, sehingga produksi dan pendapatan suatu wilayah akan dapat diketahui (Pramono dan Suminar, 2019). Produk Domestik Regional Bruto (PDRB) sebagai ukuran produksi dan pendapatan wilayah dapat dihitung dengan melakukan tiga macam pendekatan yang terdiri dari pendekatan produksi, pendekatan pendapatan, dan pendekatan pengeluaran. Produk Domestik Regional Bruto (PDRB) pada umumnya akan terlihat dalam kurun waktu satu tahun. Tahun 2020 di wilayah Provinsi Jawa Timur diketahui bahwa Produk Domestik Regional Bruto (PDRB) mengalami kontraksi pada sebagian besar lapangan usaha, tetapi masih terdapat lapangan usaha yang menjadi sumber pertumbuhan tertiggi seperti lapangan usaha pada sektor Pertanian, Kehutanan dan Perikanan yang dapat tumbuh sebesar 0,80 persen (BPS, 2020).

\section{Teori Kelembagaan}

Kelembagaan menurut Arifin (2005), diartikan sebagai seperangkat aturan yang terdapat dalam suatu organisasi atau kelompok masyarakat yang berinteraksi dan memiliki sekumpulan kepentingan yang ingin dicapai. Berdasarkan pengertian tersebut, maka terdapat 
penekanan terhadap tercapainya tujuan bersama yang telah menjadi sebuah satu-kesatuan. Kelembagaan akan menjadi sebuah wadah atau pranata bagi suatu hubungan masyarakat yang terjalin melalui kegiatan kolektif. Hubungan masyarakat yang diwadahi dalam suatu jaringan atau organisasi akan membuat setiap tindakan dan perilaku diatur oleh kaidah-kaidah baik formil maupun informil yang menjadi faktor pembatas dan pengikat. Aturan tersebut akan berguna sabagai alat kontrol sosial yang membantu masyarakat dalam mengelola kehidupannya sekaligus mengembangkan kapasitas diri. Berdasarkan kepentingannya lembaga dapat dibedakan menjadi dua, yaitu lembaga formal yang bersifat terstruktur dan lembaga non-formal yang tidak terstruktur, keduanya sama-sama akan membantu dalam mencapai tujuan tertentu. Lembaga terdiri dari beberapa jenis seperti, lembaga agama, lembaga politik, lembaga ekonomi dan lain-lain yang didasarkan pada fungsi dan tujuan berbeda, sehingga dengan dasar tersebut maka salah satunya diatur mengenai sektor agraris (sawah, perladangan, perikanan dan peternakan) pada lembaga ekonomi.

\section{Kelembagaan Pertanian}

Menurut Tjiptabudy (2015) kelembagaan pertanian merupakan norma terstruktur yang diterapkan pada masyarakat yang berkaitan dengan bidang pertanian di pedesaan dan dikembangkan dengan prinsip pemanfaatan seluruh potensi baik sumber daya manusia (SDM) maupunsumber daya alam (SDA). Kelembagaan pertanian akan membantu dalam memfasilitasi interaksi sosial dalam kehidupan komunitas petani. Terdapat beberapa bagian dalam kelembagaan pertanian seperti, kelembagaan petani, kelembagaan pemerintah pertanian, kelembagaan swasta pertanian, dan kelembagaan LSM (Lembaga Swadaya Masyarakat). Kelembagaan pertanian di pedesaan dalam praktiknya memiliki keterkaitan antara kegiatan ekonomi dan sosial. Perihal tersebut membuat kelembagaan pertanian di pedesaan bersifat tradisional. Adapun kelembagaan pertanian yang lebih bersifat modern, yaitu kelompok tani, kelompok pemasaran, koperasi desa dan sebagainya. Kelembagaan pertanian yang dikelola dengan cara lebih modern akan bersifat terstruktur dan memilikitata nilai yang diformalkan.

Menurut Soetriono dan Suwandari (2016), aspek penting kelembagaan pertanian tidak hanya mengatur segi ekonomi secara keseluruhan tapi juga dari segi ekonomi pedesaan, sehingga berperan penting bagi kehidupan petani yang basisnya di pedesaan. Kelembagaan pertanian yang memandang segi ekonomi pedesaan akan membantu seluruh aktivitas petani dalam usahataninya sekaligus meningkatkan posisi tawar petani (Nur dan Priantinah, 2012). Posisi tawar petani menjadi sebuah instrumen penting bagi petani, guna dapat bersaing dan melaksanakan kegiatan usahataninya. Melalui kelembagaan pertanian yang akan membantu dalam meningkatkan posisi tawar petani, maka kesenjangan dankerugian yang dialami petani dapat diminimalisir.

\section{Kelembagaan Pertanian "Horti Bank"}

Menurut Afrianty dkk. (2019), Lembaga keuangan merupakan lembaga yang bergerak di bidang jasa keuangan sekaligus memutar arus uang dalam perekonomian. Proses yang terjadi dalam lembaga keuangan yaitu penghimpuan dana dari masyarakat dan menyalurkannya kepada masyarakat yang membutuhkan. Fasilitas dan produk yang diberikan oleh lembaga keuangan dapat berupa layanan penyimpanan dana (tabungan) dan penyediaan jasa pinjaman (kredit). Terdapat fungsi lain dari lembaga keuangan yakni sebagai perantara antara pemilik modal dan pasar utang yang bertanggung jawab dalam penyaluran dana dari investor kepada perusahaan yang membutuhkan dana tersebut. Kelembagaan pertanian "Horti Bank" merupakan salah satu lembaga keuangan di bidang pertanian yang berperan sebagai perantara antara investor dengan petani hortikultura. Menurut Pardiansyah (2017), investasi merupakan komitmen untuk mengembangkan uang atau aset lain dengan tujuan memperoleh 
sejumlah keuntungan di masa yang akan datang. Kelembagaan Pertanian "Horti Bank" dalam praktiknya melibatkan pihak internal dan eksternal. Pihak internal yang dimaksud merupakan person yang tergabung dalam Kelembagaan Pertanian "Horti Bank" yang telah memenuhi segala persyaratan yang ditetapkan sebelumnya. Pihak internal tidak boleh merangkap sebagai pemilik modal atau investor maupun petani. Berikutnya adalah pihak eksternal yang terdiri dari pemilik modal atau investor, petani hortikultura, dan lembaga asuransi.

Menurut Nuzula dan Nurlaily (2020), investor merupakan orang atau entitas lain yang memberikan modal yang mereka miliki dengan maksud untuk mendapatkan manfaat ekonomis di kemudian hari, sehingga berorientasi untuk menghasilkan keuntungan jangka panjang. Adapun petani hortikultura merupakan seseorang yang bergerak di bidang pertanian untuk melakukan pengelolaan tanah dengan tujuan supaya dapat menumbuhkan dan memelihara tanaman hortikultura yang meliputi, buah-buahan, sayuran dan tanaman hias. Menurut Rimawati dkk. (2019), lembaga asuransi berperan sebagai pihak yang akan melakukan pertanggungan risiko petani hortikultura yang sudah ditentukan dalam polis asuransi. Terdapat kesepatan jangka waktu terhadap pertanggungan yang dilakukan pihal lembaga asuransi. Pihak tersebut akan menerima premi sebagai imbalan atas pertanggungan kerugian, kerusakan, dan kehilangan keuntungan yang dialami pihak petani hortikultura sebagai pemegang polis. Seluruh pihak yang terlibat dalam Kelembagaan Pertanian "Horti Bank" akan memiliki hak dan kewajiban yang harus dipenuhi, supaya dapat mewujudkan kelembagaan keuangan di bidang pertanian yang dapat meningkatkan taraf hidup petani khususnya petani hortikultura terdampak pandemi COVID-19

\section{NTP (Nilai Tukar Petani)}

Menurut Nirmala dkk. (2016), NTP (Nilai Tukar Petani) dapat diartikan sebagai salah satu tolak ukur kesejahteraan petani yang didasarkan pada perbandingan antara harga yang diterima petani (It) dan harga yang dibayar petani (Ib). Berdasarkan perbandingan tersebut, maka diketahui pendapatan petani mengalami kenaikan bila pendapatan petani lebih besar dari kenaikan harga produksi yang berpengaruh pada daya belinya. Kemampuan petani yang menjadi lebih baik akan berpengaruh pada daya beli petani dalam hal membiayai kebutuhan rumah tangganya. Semakin tinggi NTP maka semakin sejahtera kehidupan petani sebab peningkatan NTP juga akan meningkatkan produksi dan pendapatan, yang berpengaruh pada pertumbuhan ekonomi (Riyadh, 2015). Cakupan petani dan wilayah yang terdapat dalam NTP pada awalnya terbatas dan kemudian dikembangkan menjadi cakupan petani dengan usahatani pada sub sektor tanaman pangan, hortikultura, perkebunan, peternakan, dan perikanan secara regional dan nasional, sehingga dengan cakupan yang lebih luas NTP juga dapat menjadi indikator kesejahteraan pada setiap sub sektor pertanian (Rachmat, 2013).

\section{Penelitian Terdahulu}

Sektor pertanian dapat menjaga keberlangsungan hidup rakyat Indonesia maka tidaklah berlebihan jika sektor pertanian dikatakan sebagai tulang punggung bangsa Indonesia. Peranan penting tersebut dipegang oleh petani sebagai pelaku utama dalam pembangunan pertanian. Kondisi yang terjadi hingga saat ini justru menunjukkan bahwa sektor pertanian hanya menjadi sektor yangtermarjinalkan. Pasalnya petani di `Indonesia harus menghadapai kompleksitas permasalahan dalamkegiatan usahataninya dan hingga saat ini kesejahteraan petani juga belum tercapai. Salah satupermasalahan yang harus dihadapi oleh petani, yaitu fluktuasi hasil pertanian, sehingga terdapat resikodan ketidakpastian yang cukup tinggi. Permasalahan tersebut seringkali dihadapi oleh petanihortikultura, karena fluktuasi harga yang tinggi dalam pemasaran komoditas hortikultura sudah menjadi isu sentral yang kerap kali muncul (Irawan, 2016). Fluktuasi harga komoditas hortikulturaterjadi karena petani tidak 
bisa menyesuaikan antara volume pasokan dengan kebutuhan konsumen.

Menurut Irawan, (2016) fluktuasi harga komoditas hortikultura juga disebabkan oleh sifat produk yang musiman dan sensitif terhadap perubahan kesegaran produk, serta kondisi cuaca yang berpengaruh pada budidayanya. Fluktuasi harga menyebabkan terjadinya ketidakstabilan pada keuntungan yang diperoleh petani hortikultura, sehingga menurunkan daya tarik pelaku bisnis untuk melakukan investasi. Kondisi tersebut mempengaruhi perolehan pendapatan petani hortikultura, sedangkan sumber penghidupan petani bergantung pada pendapatan yang diperoleh. Petani harus menanggung kerugian dalam kegiatan usahataninya. Permasalahan seperti itu yang dapat menimbulkan kemiskinan pada petani. Kemiskinan yang dialami petani juga dapat disebabkan oleh kurangnya kesempatan kerja, kurangnya usaha karena terlalu berpasrah diri, dan permodalan yang terbatas yang akan dapat menghambat pengembangan kegiatan ushatani (Warto, 2015)

Keterbatasan modal juga menjadi masalah bagi petani hortikultura dalam menjalankan usahataninya. Hal tersebut dapat diatasi melalui hadirnya kelembagaan pertanian yang dapat membantu petani mulai dari penyediaan input sampai pada pemasaran hasil. Kelembagaan pembiayaan yang diharapkan dapat mengentaskan persoalan keterbatasan modal petani justru kerap mengalami kegagalan. Minimnya kelembagaan pembiayaan akibat kegagalan disebabkan adanya skim yang selama ini tidak menyentuh petani dan ketidaktepatan dalam mekanisme pembiayaan (Purwaningsih dkk., 2015). Rendahnya aksebilitas petani terhadap kelembagaan formal yang disebabkan oleh rumitnya prosedur dan ketiadaan agunan, menyebabkan petani cenderung melakukan peminjaman pada lembaga non-formal. Kelembagaan yangmenerapkan konsep asuransi pun juga mengalami kendala dan masih sangat minim untuk dipraktikkan, karena luas lahan yang dimiliki petani tidak bisa memberikan hasil yang pasti (Anugrah, 2014), Penyebaran informasi terkait kelembagaan asuransi pertanian juga kurang intensif, sehingga akses petani terhadap kelembagaan masih minim.

Lembaga keuangan yang dapat membantu dalam mengatasi keterbatasan modal di sektor pertanian, yaitu LKM-A (Lembaga Keungan Mikro Agribisnis). LKM-A dengan bisnis utamanya berupa simpan pinjam memiliki kelemahan seperti, sistem regulasi yang kurang jelas dan tidak bisa mendorong pencapaian skala ekonomis usaha, serta adanya resiko kemacetan kredit yang dapat membuat LKM-A sulit berkembang (Hanggana, 2018). Persoalan pembiayaan pertanian juga dapat diatasi melalui lembaga keuangan bank. Tentu terdapat kelemahan dari pemberian kredit oleh perbankan, yaitu lamanya waktu pencairan kredit, persyaratan agunan yang sangat memberatkan petani, dan pelayanan kredit masih terbatas.

Menurut Ashari, (2009), risiko terjadinya kerugian dan ketidakpastian yang cukup tinggi pada sektor pertanian menyebabkan terbatasnya pemberian kredit pada petani oleh pihak perbankan.Perbankan yang berperan dalam pemberian kredit pertanian di Indonesia, yaitu BPR (Bank Perkreditan Rakyat) dan bank umum seperti BRI (Bank Rakyat Indonesia). BPR dan BRI berfungsi untuk memberikan pelayanan keungan mikro. Realita yang ada justru menunjukkan bahwa pihak bank dalam pemberian kredit belum sampai pada petani dengan skala usaha yang kecil. Perbankan di Indonesia masih kurang berpihak terhadap sektor pertanian dikarenakan sektor pertanian dinilai memiliki faktor ketidakpastian yang cukup tinggi. Selang waktu pada proses produksi di sektorpertanian memungkinkan terjadinya kemacetan kredit oleh petani, sehingga hal tersebut dianggap terlalu berisiko. Petani untuk mendapatkan pinjaman kredit harus bisa memenuhi beberapa syarat seperti, mengembalikan pokok pinjaman beserta bunganya dalam waktu yang sudah ditentukan, menyerahkan agunan kepada pihak bank, peningkatan margin deposit dan sebagainya yang tentunya akan memberatkan petani dengan skala usaha kecil. Karakteristik skim kredit yang ditawarkan tersebut tentu akan mem- 
beratkan petani karena skim kredit yang ditawarkan berada di luar batas kemampuan para petani (Supriatna, 2008). Perlu adanya sebuah kelembagaan pertanian dengan konsep asuransi dan pembiayaan yang dilakukan secara sistematis, sehingga dapat membantu petani dalam menjalankan dan mengembangkan usahataninya.

\section{Kerangka Pikir dan Metodologi}

\section{Kerangka Pikir}

Produksi hasil pertanian khususnya pada sub sektor hortikultura seperti kubis dan tomat begitu tinggi, dan tidak diimbangi dengan tingkat konsumsi masyarakat membuat harga komoditas hortikultura di tingkat petani mengalami penurunan tajam sehingga membuat petani hortikultura di sejumlah wilayah Jawa Timur kini mengalami kerugian. Salah satu yang terparah terjadi di Kabupaten Malang dan Jember (Kompas, 2020). Sebagian besar hasil komoditas hortikultura seperti kubis di berbagai wilayah mengalami penurunan harga. Akibatnya banyak petani yang merugi dan bahkan beberapa petani membiarkan hasil produksinya tidak dipanen atau dibagikan ke warga sekitar secara percuma. Permasalahan ini terjadi karena komoditas hortikultura seperti sayuran di beberapa wilayah Jawa Timur tidak dapat dikirim ke luar daerah karena tertutupnya mayoritas jalur akses distribusi akibat pandemi COVID-19 dan kebijakan pemerintah terkait pembatasan sosial masyarakat, sehingga produk yang dihasilkan tidak dapat terdistribusi sampai kepada konsumen akhir.

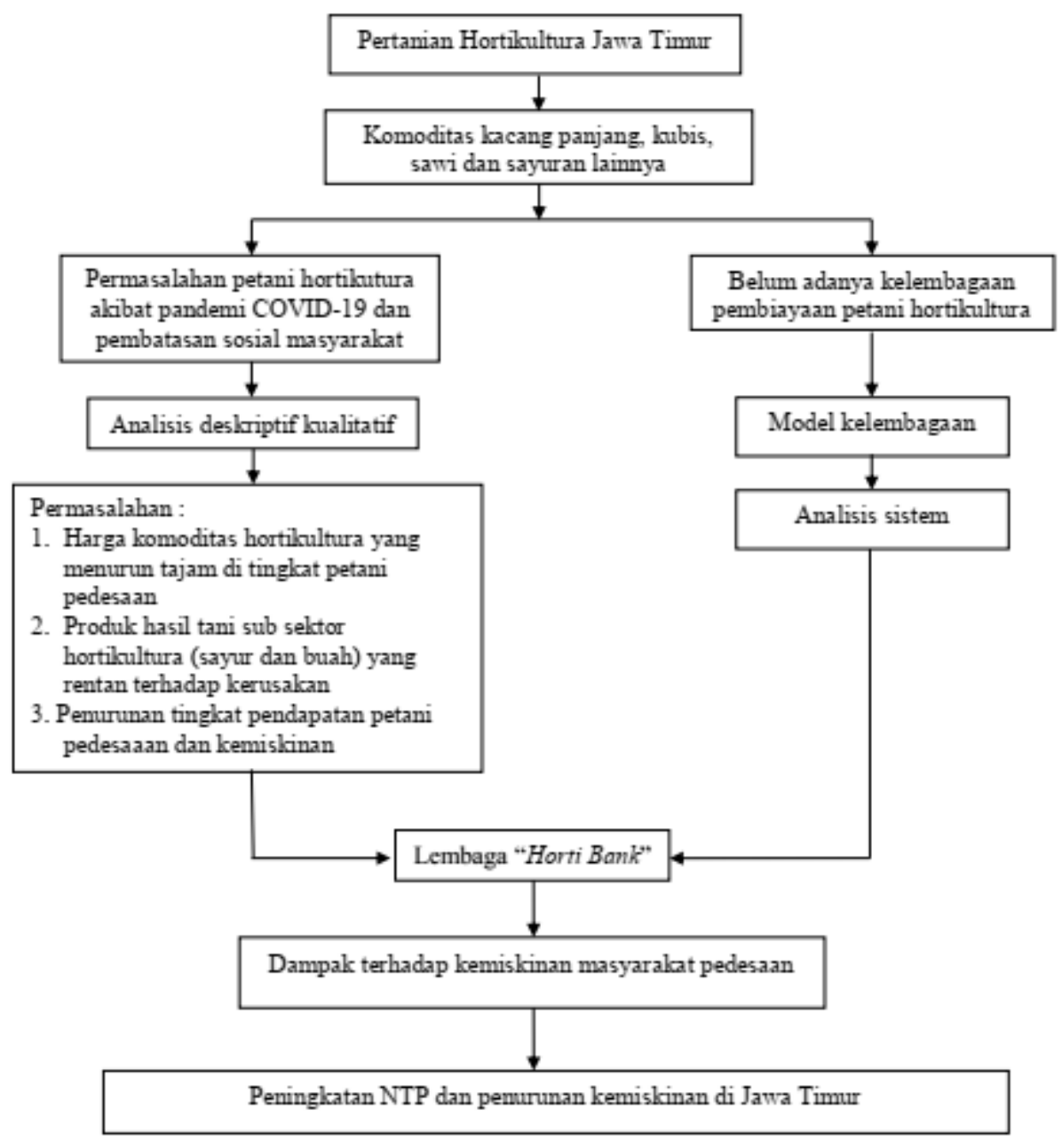

Gambar 1: Skema kerangka pemikiran

Menurut Bakri (2010), permasalahan lainnya adalah kehidupan petani di pedesaan 
yang selalu diungkapkan dengan kemiskinan dan keterbelakangan, baik dari segi mata pencaharian, cara berpikir serta sikap yang masih tradisional. Sifat yang tradisional menjadikan petani hortikultura belum mampu memanfaatkan input produksi secara maksimal, sehingga berimplikasi terhadap tingkat keuntungan yang relatif rendah apalagi di tengah pandemi COVID-19. Hal ini dikarenakan belum adanya kelembagaan yang benar- benar dapat membantu petani hortikultura dalam mengatasi kompleksitas permasalahannya mulai dari penyediaan permodalan, mengontrol kegiatan usahatani, memberikan informasi dan membantu dalam penyediaan akses pasar. Kurangnya peranan kelembagaan pertanian yang sudah ada dan minimnya pengetahuan dan akses petani terhadap informasi kegiatan usahatani hortikultura di tengah pandemi COVID-19, serta kebijakan pemerintah terkait pembatasan sosial, menyebabkan beberapa permasalahan yang dapat mempengaruhi harga jual dan tingkat pendapatan petani. Hal ini yang mendorong untuk dilakukan penelitian terkait terkait strategi dan solusi pembiayaan petani hortikultura di tengah pandemi COVID-19 untuk mengurangi tingkat kemiskinan di wilayah pedesaan Provinsi Jawa Timur. Berdasarkan permasalahan yang dialami oleh petani hortikultura tersebut, maka diperlukan solusi berupa model kelembagaan petani hortikultura yang dianalisis dengan analisis sistem. Kelembagaan petani yang mampu mengembangkan potensi pertanian khususnya pada sub sektor hortikultura di pedesaan Provinsi Jawa Timur yaitu Lembaga "Horti Bank". Lembaga "Horti Bank" diharapkan dapat meminimalisir terjadinya kerugian dan dapat meningkatkan pendapatan serta kesejahteraan masyarakat dan petani hortikultura di wilayah pedesaan Provinsi Jawa Timur.

\section{Metode Penelitian}

\section{Metode Penentuan Lokasi Penelitian}

Penelitian ini merupakan penelitian deskriptif analitis dengan metode studi kasus dan studi literatur terkait strategi dan solusi pembiayaan petani hortikultura di tengah pandemi COVID-19 untuk mengurangi tingkat kemiskinan di wilayah pedesaan Provinsi Jawa Timur. Lingkup penelitian dipilih secara sengaja (purposive) di wilayah Provinsi Jawa Timur dengan pertimbangan bahwa Jawa Timur merupakan salah satu wilayah yang terdampak pandemi COVID-19 secara sosial dan ekonomi serta merupakan wilayah yang berpotensi sebagai penghasil komoditas hortikultura.

\section{Teknik Pengumpulan Data}

Pengumpulan data pada penelitian ini dilakukan dengan metode desk study dengan menelaah berbagai literatur yang terkait dengan penelitian dan topik pembahasan. Data pada penelitian ini menggunakan data sekunder yang berupa data COVD-19, data kemiskinan dan Nilai Tukar Petani yang diperoleh dari berbagai sumber, diantaranya website resmi WHO, Gugus Tugas Percepatan Penanganan COVID-19 nasional, Jatim tanggap COVID-19, Badan Pusat Statistik (BPS) Indonesia, Badan Pusat Statistik (BPS) Provinsi Jawa Timur, Pusat Data dan Informasi Kementerian Pertanian, serta studi berbagai literatur lain seperti jurnal dan buku cetak maupun elektronik yang terkait dengan penelitian ini.

\section{Teknik Analisis Data}

Guna menganalisis permasalahan yang dihadapi petani hortikultura (buah dan sayur) dijelaskan dengan teknis analisis deskriptif kualitatif. Penjabaran analisis didasarkan pada perolehan informasi yang sesuai dengan hasil studi literatur. Metode studi literatur memiliki beberapa tujuan yaitu menginformasikan kepada pembaca hasil-hasil penelitian lain yang memiliki kaitan erat dengan penelitian yang dilakukan saat itu, menghubungkan penelitian dengan literatur-literatur yang ada, sertamengisi celah dalam penelitian-penelitian sebelumnya. Hasil dari studi literatur berupa ulasan, rangkuman, dan pemikiran penulis tentang beberapa sum- 
ber pustaka yang berasal dari jurnal, buku, laman web, media massa maupun media cetak.

Analisis mengenai kelembagaan "Horti Bank" dijelaskan dengan menggunakan analisis sistem. Pembentukan model kelembagaan "Horti Bank" sebagai solusi pembiayaan petani sayur dan buah di tengah pandemi COVID-19 untuk mengurangi angka kemiskinan di wilayah pedesaaan Provinsi Jawa Timur, dianalisis dengan pendekatan sistem sebagai berikut: (a) Analisis kebutuhan, yaitu interaksi antara respon yang tumbuh dari seseorang pengambil keputusan (desicion maker) terhadap jalannya sistem. Kebutuhan ini dapat meliputi hasil observasi atau survei, pendapat ahli, hasil diskusi, dan sebagainya (Eriyatno, 1999).; (b) Persyaratan kebutuhan, yaitu dibutuhkan untuk kelangsungan identifikasi sistem. Setiap sistem mempunyai persyaratan kebutuhan yang berbeda-beda, sehingga tidak ada ketentuan yang bersifat mutlak. Kebutuhan yang dianggap memenuhi syarat dalam analisis ini adalah dilihat kedekatannya dalam konteks pembentukan model kelembagaan.; (c) Identifikasi sistem, yaitu rantai hubungan antara pernyataan kebutuhan-kebutuhan dengan pernyataan khusus dari masalah yang harus dipecahkan untuk untuk melengkapi dari kebutuhan-kebutuhan tersebut (Eriyatno, 1999).

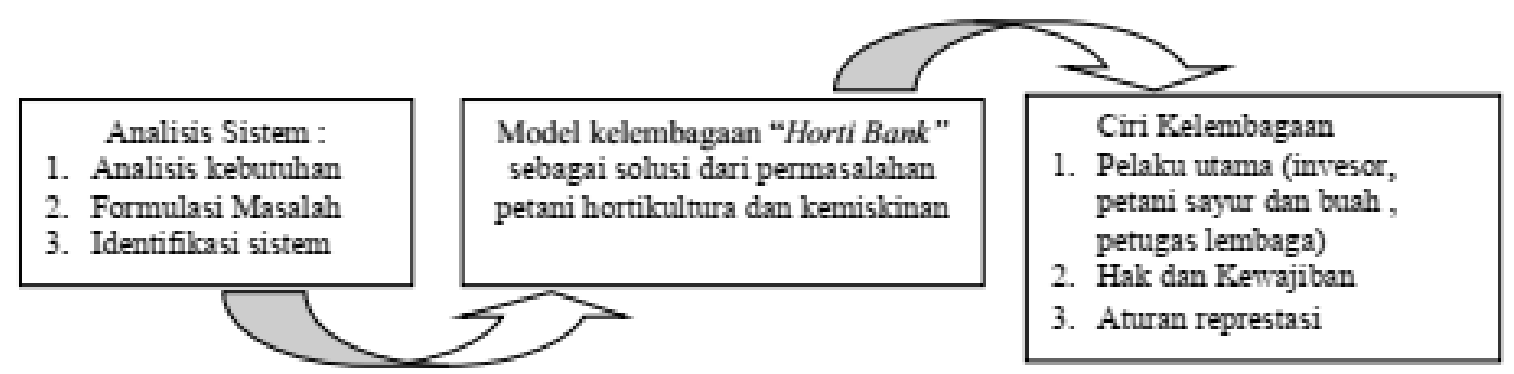

\section{Gambar 2: Analisis Pendekatan Sistem}

Untuk mengetahui dampak dari adanya penerapan kelembagaan "Horti Bank" dalam mengurangi kemiskinan di pedesaan digunakan analisis perhitungan NTP (Nilai Tukar Petani). Metode analisis yang digunakan untuk menghitung NTP (Nilai Tukar Petani) merupakan hasil formulasi dari Indeks harga Laspeyres seperti yang telah dikembangkan oleh BPS tahun 1995. Nilai Tukar Petani (pangan, peternakan, perikanan) didefinisikan sebagai rasio antara harga yang diterima petani $(\mathrm{HT})$ dengan harga yang dibayar petani $(\mathrm{HB})$ atau dapat diformulasikan ke dalam rumus:

$$
N T P=(I t / I b) \times 100 \%
$$

Keterangan:

NTP

It

Ib
: Nilai Tukar Petani

: Indeks harga yang diterima oleh petani

: Indeks harga yang dibayarkan oleh petani

Dengan kriteria:

NTP $>100$ berarti petani mengalami surplus dan sejahtera

NTP $=100$ berarti petani mengalami BEP dan belum sejahtera

NTP $<100$ berarti petani mengalami defisit dan tidak sejahtera

Komponen yang mempengaruhi It adalah harga jual komoditas yang diterima oleh petani. Harga yangditerima oleh petani tersebut dipengaruhi oleh beberapa hal diantaranya adalah nilai produksi, kualitasproduksi, informasi pasar, sistem pemasaran, dan posisi tawar petani. Komponen yang mempengaruhi Ib diantaranya adalah meliputi biaya produksi usahatani dan biaya konsumsi rumah tangga petani. 


\section{Hasil dan Pembahasan}

\section{Identifikasi Permasalahan Pembiayaan Petani Hortikultura pada Masa Pandemi COVID- 19 di Wilayah Provinsi Jawa Timur}

Adanya COVID-19 dan kebijakan-kebijakan yang terkait di dalamnya dikatakan telah menggeser struktur yang ada termasuk kaitannya dengan usahatani hortikultura yang ada di Jawa Timur ini. Kebijakan PSBB dapat menghambat distribusi dalam pemasokan produk hortikultura. Akibat tersendatnya distribusi tersebut dapat menurunkan kualitas dari produk hortikultura itu sendiri dikarenakan produk hortikultura bersifat perishable atau mudah rusak. Daya simpan produk hortikultura juga tidak selama daya simpan produk tanaman pangan maupun tanaman perkebunan (Iriani, 2020). Selain itu, adanya masa pandemi ini juga dapat menurunkan tingkat konsumsi masyarakat terhadap produk hortikultura. Penurunan permintaan produk yang tidak diimbangi dengan produksi dapat menyebabkan kelebihan pasokan, akibatnya harga produk hortikultura anjlok dipasaran. Anjloknya harga produk hortikultura juga banyak terjadi di daerah Jawa Timur yang tentu akan merugikan para petani hortikultura.

Di Kabupaten Magetan Jawa Timur harga kubis selama pandemi berlangsung mengalami penurunan harga yang drastis. Harga kubis yang biasanya berkisar Rp 3.000-Rp 4.000 per kilogram mendadak turun menjadi Rp 500 per kilogramnya. Turunnya harga kubis disebabkan ketentuan harga yang diberikan oleh tengkulak memang rendah, dikarenakan tengkulak sendiri khawatir tidak dapat menjual produk ke kota besar akibat semakin ketatnya kebijakan pembatasan operasional pasar dimasa pandemi ini (SariAgri, 2020). Di Kabupaten Jember harga kubis yang biasanya Rp 3.000 perkilogram menjadi Rp 200 perkilogram (Kompas, 2020). Di Kabupaten Kediri harga tomat yang pernah menyentuh harga Rp 8.000 per kilogram saat ini hanya berkisar Rp 1.000 perkilogram. Di Kabupaten Malang, harga cabai yang biasanya Rp 40.000 per kilogram, saat ini hanya Rp 20.000 per kilogramnya. Anjloknya harga komoditas hortikultura yang berangsur-angsur dapat menyebabkan petani mengalami kesulitan permodalan untuk panen selanjutnya, untuk itu diperlukan dukungan lembaga pembiayaan usahatani.Namun lembaga pembiayaan yang ada juga kerap menyulitkan petani terkait struktur dan akses permodalan.

Struktur dan akses permodalan yang sulit dapat menghambat petani dalam pembiayaan usahataninya. Produksi hortikultura sangat tergantung dengan musim sehingga memiliki risiko tinggi, selain itu masih relatif sedikitnya petani hortikultura yang berorientasi pada pasar dan agripreneurship, hal ini juga diperparah dengan terbatasanya akses dukungan dari layanan pembiayaan (modal) (Utami dkk., 2021). Kendala petani hortikultura yang berkaitan dengan rendahnya sistem pembiayaan yangada dapat disebabkan oleh beberapa hal. Pertama, petani hortikultura umumnya memiliki kemampuanpenyediaan modal yang relatif kecil di samping kebutuhan biaya pemeliharaan tanaman hortikultura cukup besar. Modal biasanya didapatkan dari penyisihan pendapatan petani pada panen sebelumnya. Apabila panen sebelumnya petani merugi, otomatis akan menghambat penyediaan modal produksi selanjutnya. Kondisi ini yang akhirnya menyebabkan petani terpaksa mencari pinjaman secara informal, seperti tengkulak. Minimnya pilihan lembaga pembiayaan yang ada sering menyebabkan petani terjerat pada sistem pinjaman yang merugikan petani secara ekonomi (Sunartomo, 2014).

Kedua, daya tawar petani yang rendah mengharuskan petani untuk memanfaatkan saluran tataniaga yang melibatkan tengkulak, hal ini didukung dari minimnya informasi pasar di tingkat petani. Proses penjualan hasil produksi ke tengkulak memang relatif lebih cepat dan mudah, namun minimnya informasi pasar tersebut dapat menyebabkan rendahnya harga jual di tingkat petani. Keberadaan tengkulak juga memperpanjang rantai pemasaran dan memperbesar margin pemasaran. Perilaku pasar juga menunjukkan bahwa harga lebih banyak diten- 
tukan oleh pihak pedagang atau dalam hal ini ialah tengkulak (Prayitno dkk., 2013). Eratnya keterikatan sosial yang ada antara petani dengan tengkulak juga mempengaruhi pengambilan keputusan petani untuk melalukan pinjaman di tengkulak.

Ketiga, adanya campur tangan pada sistem birokrasi pemerintah yang berlebihan juga dapat melumpuhkan kelembagaan pembiayaan lokal yang ada di masyarakat. Sistem birokrasi yang rumit tentunya menyulitkan petani dalam mengakses kelembagaan pambiayaan tersebut. Disisi lain, rendahnya SDM petani akibat penurunan petani muda baik secara relatif maupun absolut serta fenomena aging farmer juga menyulitkan petani kita saat ini untuk memahami sistem akses terhadap pembiayaan tersebut (Susilowati, 2016). Permasalahan tersebut yang menyebabkan SDM petani banyak tergolong ke dalam usia tua yang tentu akan berimplikasi pada penurunan aksebilitas petani dalam penyerapan sumberdaya modal, informasi pasar, teknologi, maupun kemampuan petani itu sendiri (Pratiwi dkk., 2019). Rendahnya aksesibilitas petani dapat menjadi faktor penghambat dalam melakukan pengembangan pada usahataninya.

Keempat, sistem kredit pembiayaan pertanian yang umumnya memiliki sistem bunga tetap (fix interest). Kendala besarnya bunga yang diperparah dengan pendeknya rentang waktu pengembalian dana semakin membuat petani hortikultura terjepit. Padahal komoditas hortikultura memiliki ketidakpastian dan risiko tinggi terhadap jumlah produktivitas maupun fluktuasi harga. Ketika harga jual produk rendah dan tidak sebanding dengan modal yang sudah petani keluarkan dapat menyulitkan petani dalam melakukan pembayaran pinjaman ketika jatuh tempo sehingga dapat menjerat petani ke dalam hutang yang berangsur-angsur semakin membengkak akibat bunga tersebut (Keumala \& Zainuddin, 2018). Budaya persepsi para petani terhadap bunga tinggi yang akan selalu menjerat juga telah menjadi alasan petani untuk tidak memilih lembaga formal sebagai penyedia pembiayaan usaha tani (Supanggih \& Widodo, 2013).

Kelima, adanya gap antara petani dan lembaga pembiayaan yang ada. Petani yang berperan sebagai peminjam berada pada sektor riil, sedangkan lembaga pembiayaan baik formal maupun informal dapat dikatakan berada pada sektor moneter. Jika terjadi kegagalan dalam usahatani seperti gagal panen maka akan dibebankan kepada petani selaku peminjam dan pelaku usahatani, sementara lembaga pembiayaan tetap mendapatkan keuntungan dari suku bunga yang telah ditetapkan sebelumnya (Keumala \& Zainuddin, 2018).

Keenam, saat ini pembiayaan maupun kredit yang diberikan oleh lembaga formal seperti bank umum maupun bank umum syariah lebih diutamakan pada sektor non pertanian. Hal tersebut tentunya dikarenakan rendahnya risiko sektor non pertanian jika dibandingkan dengan sektor pertanian. Sektor pertanian yang berisiko pada terjadinya kegagalan panen dan juga dihadapkan pada fluktuasi harga yang tinggi memang mampu menurunkan minat kelembagaan dalam memberikan kredit pembiayaan baik bank umum, bank syariah, maupun lembaga lainnya guna mencegah terjadinya kemacetan kredit.

Tabel 1: Kredit LP ke Sektor Ekonomi Utama oleh Bank Umum

\begin{tabular}{cccccccc}
\hline \multirow{2}{*}{ Sektor } & $\mathbf{2 0 1 8}$ & \multicolumn{2}{c}{$\mathbf{2 0 1 9}$} & \multicolumn{2}{c}{$\mathbf{2 0 2 0}$} \\
\cline { 2 - 9 } & Total & I & II & III & IV & I & II \\
\hline Industri Pengolahan & 154.058 & 147.548 & 152.240 & 159.328 & 168.773 & 152.661 & 144.814 \\
\hline Perdagangan & 126.488 & 128.424 & 131.080 & 131.339 & 132.291 & 132.146 & 128.797 \\
\hline Sektor Pertanian & 15.130 & 16.473 & 18.000 & 18.560 & 18.876 & 21.177 & 21.888 \\
\hline \multicolumn{1}{c}{ Total } & $\mathbf{2 7 2 . 4 9 7}$ & $\mathbf{2 9 2 . 4 4 6}$ & $\mathbf{3 0 1 . 3 1 9}$ & $\mathbf{3 0 9 . 2 2 7}$ & $\mathbf{3 1 9 . 9 4 0}$ & $\mathbf{3 0 5 . 9 8 4}$ & $\mathbf{2 9 5 . 5 0 0}$ \\
\hline
\end{tabular}

Sumber : Bank Indonesia (diolah) 
Tabel 2: Pembiayaan LP ke Sektor Ekonomi Utama oleh Bank Syariah

\begin{tabular}{|c|c|c|c|c|c|c|c|}
\hline \multirow[t]{2}{*}{ Sektor } & \multirow{2}{*}{$\begin{array}{l}2018 \\
\text { Total } \\
\end{array}$} & \multicolumn{4}{|c|}{2019} & \multicolumn{2}{|c|}{2020} \\
\hline & & $\mathbf{I}$ & II & III & IV & $\mathbf{I}$ & II \\
\hline Industri Pengolahan & 4.266 & 4.267 & 4.268 & 4.269 & 4.270 & 4.271 & 4.272 \\
\hline Perdagangan & 4.282 & 4.283 & 4.284 & 4.285 & 4.286 & 4.287 & 4.288 \\
\hline Pertanian & 876 & 877 & 878 & 879 & 880 & 881 & 882 \\
\hline Total & 8.984 & 8.985 & 8.986 & 8.987 & 8.988 & 8.989 & 8.990 \\
\hline
\end{tabular}

Sumber : Bank Indonesia (diolah)

Berdasarkan Tabel 1 dan Tabel 2, dapat disimpulkan bahwa kredit maupun pembiayaan yang dilakukan oleh bank umum maupun bank syariah pada sektor pertanian masih rendah. Pembiayaan dan kredit lebih diberdayakan pada sektor non pertanian seperti industri pengolahan maupun perdagangan. Dukungan pihak perbankan yang rendah terhadap petani dalam proses pembiayaan usahatani termasuk pada sub sektor hortikultura menjadikan banyak petani memperoleh hasil pendapatan yang kurang maksimal karena keterbatasan biaya produksi. Adanya kelembagaan perbankan yang belum dapat membantu petani hortikultura secara maksimal dalam mengatasi permasalahannya menunjukkan bahwa peranan kelembagaan tersebut belum optimal dalam meningkatkan kesejahteraan petani.

Permasalahan lainnya adalah kehidupan petani wilayah di pedesaan yang selalu diasumsikan dengan kemiskinan dan keterbelakangan, baik dari segi mata pencaharian, cara berpikir serta sikap yang masih tradisional. Petani hortikultura banyak yang belum mampu memanfaatkan input produksi secara maksimal, sehingga mengakibatkan tingkat keuntungan yang relatif rendah. Permasalahan ini menjadi lebih kompleks dengan minimnya pengetahuan dan akses petani terhadap informasi kegiatan usahatani hortikultura, serta kebijakan pemerintah terkait pembatasan sosial kebijakan pemerintah terkait pembatasan sosial dimasa pandemi COVID-19 yang dapat mempengaruhi harga jual dan tingkat pendapatan petani. Berdasakan berbagai permasalahan petani hortikultura terkait terkait kelembagaan pembiayaan yang yang mampu berperan dalam pembangunan sektor pertanian utamanya hortikultura, terlebih di masa pandemi ini

Sistem Kelembagaan yang Tepat Sebagai Solusi Permasalahan Pembiayaan Petani Hortikultura Pada Masa Pandemi COVID-19 Di Wilayah Provinsi Jawa Timur

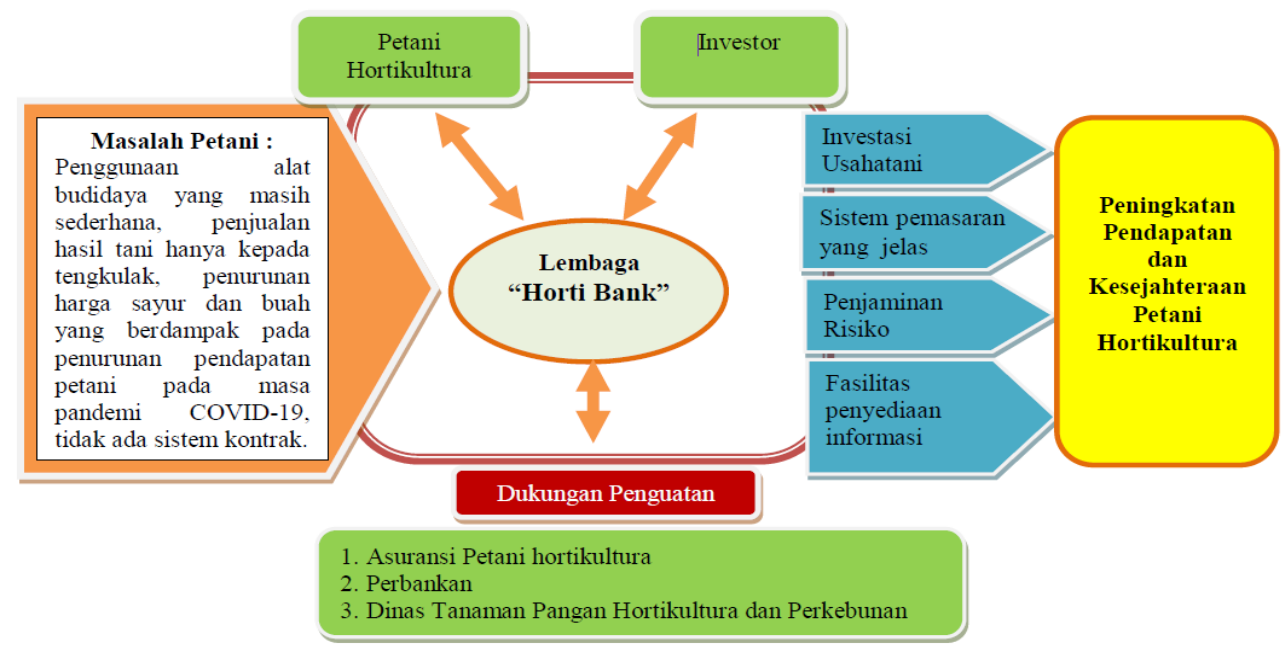

Gambar 3: Bagan Pihak-Pihak dalam Lembaga "Horti Bank" 
Diketahui bahwa permasalahan yang telah dialami petani hortikultura Jawa Timur pada masa pandemi COVID-19 mengakibatkan ketidakpastian pendapatan dan kekurangan dalam penyediaan modal produksi. "Horti Bank" merupakan salah satu lembaga yang dapat mengatasi permasalahan tersebut melalui sistem investasi. Dalam penerapannya Lembaga "Horti Bank" melibatkan pihak internal dan pihak eksternal. Pihak internal adalah lembaga "Horti Bank" itu sendiri. Pihak eksternal antara lain petani, investor dan lembaga asuransi. Pihak yang terlibat dalam Lembaga "Horti Bank" digambarkan pada gambar 3 diatas.

\section{Internal (Lembaga "Horti Bank")}

Kriteria dari pihak yang diperbolehkan menjadi lembaga "Horti Bank" antara lain bertanggungjawab, bersifat independen (tidak boleh merangkap sebagai pemilik modal atau investor maupun petani), jujur dan komunikatif, dan memiliki pengetahuan cukup mengenai kegiatan usahatani hortikultura (buah dan sayur) dari kegiatan hulu hingga kegiatan hilir. Kriteria yang paling utama adalah persondalam lembaga "Horti Bank" haruslah independen dan tidak terlibat sebagai petani maupun investor.

\section{Eksternal}

Pihak Eksternal terdiri dari investor, petani hortikultura dan lembaga asuransi. Pemilik modal atau investor harus bersifat kooperatif dengan segala aturan investasi Lembaga "Horti Bank", contoh dengan sistem bagi hasil yang ditetapkan. Sementara Petani hortikultura harus memiliki pengalaman dalam kegiatan budidaya tanaman hortikultura baik tanaman buah-buahan ataupun sayuran, sementara bagi calon petani baru yang ingin bergabung dalam kelembagaan "Horti Bank" dan belum pernah melakukan usahatani hortikultura maka petani diwajibkan untuk mengikuti pelatihan, bertanggung jawab dan jujur, bersedia mematuhi aturan dalam menjalankan usahatani hortikultura, dan berdomisili tetap pada lokasi usahatani. Lembaga asuransi merupakan pihak yang sangat penting di mana dengan adanya lembaga asuransi dapat menjamin risiko yang terjadi terhadap petani dan kerusakan atau hilangnya sarana budidaya tanaman hortikultura.

\section{Hak dan Kewajiban Pelaku dalam Sistem Lembaga "Horti Bank"}

Investor, petani, lembaga "Horti Bank" dan asuransi petani memiliki hak dan kewajiban masing-masing dalam kegiatan investasi. Hak dan kewajiban masing-masing pihak dijelaskan pada tabel 3 berikut.

Tabel 3: Hak dan Kewajiban pelaku dalam sistem lembaga“Horti Bank"

\begin{tabular}{cll}
\hline \multicolumn{3}{c}{ Investor } \\
\hline $\begin{array}{l}\text { Kewajiban } \\
\text { a. Memberikan dana investasi yang sesuai dengan }\end{array}$ & $\begin{array}{l}\text { a. Mendapatkan keuntungan sesuai bagi } \\
\text { hasil yang telah ditetapkan }\end{array}$ \\
\hline \multicolumn{4}{c}{} & \\
\hline Kewajiban & Lembaga “Horti Bank" & Hak \\
\hline
\end{tabular}

a. Menetapkan segala aturan investasi yang adil bagi kedua pihak

b. Mengatur sistem investasi dari awal hingga mendapatkan keuntungan

c. Melakukan kerjasama dengan pihak ketiga yaitu pihak platform pemasaran digital guna menunjang proses pemasaran produk. a. Mendapatkan biaya transaksi sebesar $4 \%$ dari keuntungan 
Lembaga "Horti Bank"

Kewajiban

Hak

d. Membagi hasil biaya transaksi dengan pihak ketiga dengan pembagian masing-masing 1:1

e. Melakukan control bagi kedua belah pihak Memberikan modal bagi petani dengan tanpa agunan

f. Memberikan rating kepada petani

\begin{tabular}{cll}
\hline \multicolumn{1}{c}{ Petani Hortikultura (Sayur dan Buah) } \\
\hline Kewajiban & & \multicolumn{1}{c}{ Hak } \\
\hline a. Melakukan kegiatan budidaya tanaman hortikul- & a. & Mendapatkan keuntungan sesuai bagihasil \\
tura (sayur dan buah) sesuai SOP yang ditetapkan & b. & yang ditetapkan \\
& c & $\begin{array}{l}\text { Mendapatkan jaminan modal untuk pem- } \\
\end{array}$ \\
& d. & biayan \\
& & Mendapatkan jaminan pendapatan \\
\hline
\end{tabular}

\begin{tabular}{cll}
\hline \multicolumn{3}{c}{ Asuransi Petani } \\
\hline \multicolumn{3}{c}{ Kewajiban } \\
\hline a. Memberikan jaminan asuransi kepada petani & a. & dddMendapatkan biaya premi asuransi \\
\hline
\end{tabular}

Sistem Investasi dalam Lembaga "Horti Bank"

Komoditas hortikultura yang dapat diinvestasikan pada lembaga "Horti Bank" yaitu berupa sayuran dan buah-buahan. Berikut merupakan aturan dasar investasi pada lembaga "Horti Bank":

1. Nominal investasi untuk satu hektar lahan komoditas hortikultura adalah senilai Rp 5.000.000-50.000.000,- tergantung pada jenis komoditas yang dibudidayakn dengan jangka waktu investasi selama 3 bulan.

2. Satu hektar lahan terdiri dari satu kelompok tani yang beranggotakan 5-10 petani. Investor bebas menentukan berapa pun luas lahan yang ingin diinvestasikan. Lahan yang dipilih akan digabung dengan lahan investor lain dengan sistem kolektif.

3. Horti Bank menggunakan sistem kolektif, di mana seluruh lahan yang nantinya dirawat adalah milik bersama seluruh investor, sesuai dengan jumlah lahan yang diinvestasikan. Tidak ada investor yang memiliki lahan tertentu secara spesifik.

4. Pembagian keuntungan menggunakan sistem bagi hasil (Profit \& Loss Sharing). Di mana pembagian keuntungan antara Investor, petani mitra, dan Horti Bank adalah 45:51:4

PENTING: bukan fixed-return, akadnya adalah bagi hasil, apapun yang terjadi akan ditanggung bersama oleh Horti Bank, Petani dan Investor, baik untung maupun rugi.

5. Masa periode investasi adalah satu musim tanam ( 3 bulan), keuntungan beserta modal awal akan investor terima setelah hasil panen terjual di bulan ke-3.

6. Simulasi perhitungan keuntungan usahatani hortikultura dalam satu hektare

Tabel 4: keuntungan usahatani hortikultura dalam satu hektare

\begin{tabular}{clccc}
\hline No & Komoditas & Nilai Produksi (000Rp) & Biaya Produksi(000Rp) & Keuntungan(000Rp) \\
\hline 1 & Bayam & $103.972,3$ & $49.090,0$ & $54.882,3$ \\
\hline 2 & Buncis & $45.190,1$ & $42.883,9$ & $23.06,2$ \\
\hline 3 & Cabai Rawit & $70.316,6$ & $43.029,5$ & $27.287,1$ \\
\hline 4 & Kacang panjang & $44.810,1$ & $36.092,7$ & $8.717,4$ \\
\hline 5 & Kentang & $74.807,1$ & $57.202,1$ & $17.605,0$ \\
\hline 6 & Kubis & $42.487,4$ & $36.384,0$ & $6.103,4$ \\
\hline 7 & Sawi & $98.522,9$ & $58.686,3$ & $39.836,6$ \\
\hline
\end{tabular}




\begin{tabular}{clccc}
\hline No & Komoditas & Nilai Produksi (000Rp) & Biaya Produksi(000Rp) & Keuntungan(000Rp) \\
\hline 8 & Wortel & $30.603,8$ & $21.628,0$ & $8.975,8$ \\
\hline 9 & Semangka & $47.816,5$ & $28.326,9$ & $19.489,6$ \\
\hline 10 & Tomat & $89.944,3$ & $62.217,5$ & $27.726,8$ \\
\hline
\end{tabular}

Sumber: Badan Pusat Statistik 2019 (diolah)

Simulasi perhitungan keuntungan (1 Hektare, dengan harga investasi per hektare Rp 5.000.000-50.000.000)

Profit rata-rata 1 hektar usahatani hortikultura = Rp 20.000.000,-

Profit untuk investor $45 \%=$ Rp 9.000.000,-

Return Investor = modal awal + profit 1hektare

$=\operatorname{Rp} 5000.000+\operatorname{Rp} 9000.000$

$=\operatorname{Rp} 14.000 .000$

\section{* catatan}

a. Jika lebih dari 1 hektare, keuntungan yang didapat hanya tinggal dikali dengan keuntungan 1 hektare.

b. Angka profit rata-rata 1 hektar usahatani subsektor hortikultura di atas adalah estimasi. Bisalebih atau kurang dari angka tersebut.

Lembaga "Horti Bank" juga diperkuat dengan adanya lembaga perbankan sebagai lembaga penghimpun dan penyalur keuangan masyarakat yang bertujuan untuk menunjang pelaksanaan pembangunan salah satunya dalam investasi bidang pertanian pada sub sektor hortikultura melalui perantara lembaga "Horti Bank" sebagai pengatur sistem investasi. "Horti Bank" juga menjalankan perannya dengan dukungan penguatan dari dinas terkait seperti Dinas Tanaman Pangan dan Hortikultura sebagai perumus kebijakan teknis pengelolaan urusan dibidang perbenihan dan perlindungan tanaman salah satunya pada bidang produksi tanaman hortikultura

\section{Dampak Kelembagaan "Horti Bank" Terhadap Nilai Tukar Petani (NTP) dan Tingkat Kemi- skinan Di Wilayah Pedesaan Provinsi Jawa Timur}

Pandemi COVID-19 di Provinsi Jawa Timur telah memberikan dampak penurunan terhadap Nilai Tukar Petani (NTP) terutama pada bulan Mei hingga September 2020 yang mengalami rata-rata penurunan sebesar 95,59\%. Adanya kelembagaan "Horti Bank" dimasa pandemi COVID-19 akan menghasilkan nilai tukar petani yang berbeda dengan. sebelum adanya kelembagaan "Horti Bank".Simulasi perhitungan nilai tukar petani dapat dilihat pada tabel 4.3 berikut.

Tabel 5: Perbandingan Nilai Tukar Petani

\begin{tabular}{lccc}
\hline Subsektor Hortikultura & $\begin{array}{c}\text { It (Indeks Harga yang } \\
\text { Diterima Petani) }\end{array}$ & $\begin{array}{c}\text { Ib (Indeks Harga yang } \\
\text { Dibayar Petani) }\end{array}$ & $\begin{array}{c}\text { NTP (Nilai Tukar } \\
\text { Petani) }\end{array}$ \\
\hline Sebelum terdampak COVID-19 & 110,07 & 105,87 & 103,98 \\
\hline Saat terdampak COVID-19 & 99,23 & 106,31 & 93,34 \\
\hline Adanya Kelembagaan “Horti Bank” & 139.72 & 124.66 & 112.08 \\
\hline
\end{tabular}

Sumber: BPS 2020 (diolah)

\section{Simulasi perhitungan Nilai Tukar Petani dengan adanya kelembagaan "Horti Bank"}

1. NTP sebelum terdampak COVID-19 $\times 100 \%=x 100 \%=103,98$

2. NTP saat terdampak COVID-19 $\times 100 \%=\times 100 \%=93,34$

3. NTP dengan adanya kelembagaan "Horti Bank" 
Dengan asumsi dengan adanya kelembagaan "Horti Bank" mangalami penurunan Ib sebesar $7.5 \%$ dan kenaikan It sebesar $10 \%$

a. Ib subsektor hortikultira dengan adanya kelembagaan "Horti Bank" $=0.925 \times \mathrm{lb}$ hortikultura terdampak COVID-19=0.925 x 106,31=98,337\%

b. It sub sektor hortikultira dengan adanya kelembagaan "Horti Bank" = $10 \mathrm{x}$ It hortikultura terdampak COVID-19=1,10 x 99,23=109,35\%

c. NTP hortikultura dengan kelembagaan "Horti Bank" $\times 100 \%=\times 100 \%=111,20 \%$

Nilai tukar petani ketika adanya penerapan Kelembagaan "Horti Bank" mengalami peningkatan sebesar 15,617 persen. Hal ini dikarenakan dengan adanya lembaga "Horti Bank" mengakibatkan indeks harga yang dibayarkan oleh petani (Ib) akan menurun. Menurunnya Ib karena adanya pemberian jaminan modal dari investor. Di samping itu, terdapat perubahan indeks harga yang diterima oleh petani (It) yang mengalami peningkatan dikarenakan adanya akses pasar yang jelas dimasa pandemi COVID-19 dan penjaminan harga jual hasil dari suatu komoditas dengan besaran harga yang menguntungkan untuk petani. Dengan nilai Ib yang lebih rendah dan nilai It yang lebih tinggi akan menyebabkan nilai tukar petani ketika adanya lebih besar dibanding ketika masing-masing komoditas hortikultura. Berdasarkan hal tersebut, adanya kelembagaan "Horti Bank" akan mampu meningkatkan kesejahteraan petani dilihat dari nilai NTP yang meningkat menjadi 111,20 persen. Pada akhirnya akan berimplikasi terhadap penurunan tingkat kemiskinan di Jawa Timur.

\section{Kesimpulan dan Rekomendasi Kebijakan}

\section{Kesimpulan}

Berdasarkan pembahasan di atas maka diperoleh beberapa kesimpulan yaitu:

1. Kelembagaan pembiayaan di sektor pertanian selama ini peranannya dirasa kurang efektif dan efisien, sehingga petani hortikultura di Provinsi Jawa Timur masih mengalami permasalahan keterbatasan modal. Kerugian dari hasil penjualan produk hortikultura juga menjadi permasalahan lain yang dialami oleh petani hortikultura di Provinsi Jawa Timur. Adanya pandemi COVID-19 semakin memperparah permasalahan petani hortikultura di Jawa timur. Penerapan kebijakan PSBB (Pembatasan Sosial Berskala Besar) dalam rangka percepatan penanganan COVID-19 secara nyata telah berdampak pada Nilai Tukar Petani (NTP). Diketahui Nilai Tukar Petani (NTP) sebelum adanya pandemi COVID-19 bernilai 103,97 persen, sedangkan pada masa pandemi COVID-19 Nilai Tukar Petani (NTP) mengalami penurunan pada nilai 95,59 persen yang artinya pendapatan petani lebih kecil sebesar 4,41 persen dari pengeluarannya.

2. Lembaga "Horti Bank" merupakan model kelembagaan yang menerapkan sistem investasi dengan melibatkan pihak internal (Lembaga "Horti Bank") dan pihak eksternal (petani hortikultura, investor, lembaga asuransi). Seluruh pihak yang diperbolehkan untuk terlibat dalam Lembaga "Horti Bank" harus memenuhi kriteria yang sudah ditetapkan. Lembaga "Horti Bank" dalam pelaksanaannya juga memerlukan dukungan dari pihak asuransi petani hortikultura, perbankan, Dinas Tanaman Pangan Hortikultura dan Perkebunan. Lembaga "Horti Bank" sebagai mediator antara petani mitra dengan pemilik modal (investor) secara nyata dapat menguntungkan masing- masing pihak dan sekaligus akan membantu dalam meningkatkan kesejahteraan petani hortikultura di Provinsi Jawa Timur.

\section{Rekomendasi Kebijakan}

Berdasarkan hasil penelitian terkait permasalahan petani hortikultura disarankan dapat menerapkan model Kelembagaan "Horti Bank" supaya kompleksitas permasalahan 
petani hortikulturadi Provinsi Jawa Timur dapat teratasi. Lembaga "Horti Bank" sebagai suatu solusi dapat diterapkan di berbagai daerah Provinsi Jawa Timur yang memproduksi tanaman hortikultura guna meningkatkan kesejahteraan petani hortikultura.

\section{Daftar Pustaka}

Afrianty, N., D. Isnaini, dan A. Oktarina. (2019). Lembaga Keuangan Syariah. Penerbit CV Zigie Utama.

Aminudin, Muhammad. (2020). Harga Anjlok Gegara Pandemi, Petani Cabai di Malang Merintih. Detik News.

Anantanyu, S. (2011). Kelembagaan petani : peran dan strategi pengembangan kapasitasnya. 7(2):102-109.

Anugrah, D. S. G. C. (2014). Perlindungan petani melalui konsep asuransi. 1:92-108.

Arifin, B. (2005). Pembangunan Pertanian: Paradigma Kebijakan Dan Strategi Revitalisasi. Gramedia Widiasarana Indonesia.

Ashari. (2009). Peran perbankan nasional dalam pembiayaan sektor pertanian roles of national banking in agricultural finance in indonesia. Forum Pnenelitian Agro Ekonomi. 27(1):13-27.

Aspiansyah, A. dan A. Damayanti. (2019). Model pertumbuhan ekonomi indonesia: peranan ketergantungan spasial. Jurnal Ekonomi Dan Pembangunan Indonesia. 19(1):62-83.

Badan Pusat Statistik. 2019. Basic statistics of indonesia. Statistik Indonesia 2019 (Indonesian Statistics). 7-7.

BPS Jawa Timur. (2020). Berita resmi statistik provinsi jawa timur. Badan Pusat Statistik Prov Jawa Timur. 08(52):1-12.

Badan Pusat Statistika. (2020). Statistik indonesia 2020. Statistical Yearbook of Indonesia. 1101001(April):192.

Bakri, A. H. S. (2010). Strategi Buruh Tani dalam Memenuhi Kebutuhan Pokok (Studi Pada Buruh Tani Di Dusun Calok, Desa Arjasa, Kecamatan Arjasa, Kabupaten Jember). Universitas Jember.

Elizabeth, R. (2019). Revitalisasi implementasi pemberdayaan kelembagaan pertanian berkesinambungan mendukung pencapaian daya saing produk olahan. UNES Journal of Scientech Research. 4(1):52-68.

Eriyatno. (1999). Ilmu sistem: Meningkatkan mutu dan efektivitas manajemen. Jilid satu. IPB Press

Hanggana, S. (2018). Analisis kelemahan regulasi poktan, gapoktan, UPJA, dan LKM-A dalam peningkatan pendapatan petani. Analisis Kebijakan Pertanian, 15(2):137-149.

Irawan, B. (2016). Fluktuasi harga, transmisi harga, dan marjin pemasaran sayuran dan buah. Analisis Kebijakan Pertanian. 5(4):358-373.

Iriani, F. (2020). Fisiologi Pascapanen Untuk Tanaman Hortikultura. Deepublish.

Keumala, C. M., \& Zainuddin, Z. (2018). Indikator Kesejahteraan Petani melalui Nilai Tukar Petani (NTP) dan Pembiayaan Syariah sebagai Solusi. Economica: Jurnal Ekonomi Is- 
Horti Bank: The Concept of Agricultural Financing Through Farmer

lam, 9(1), 129-149.

Kompas. (2020). Harga Kubis Anjlok, Petani di Jember Biarkan Tanaman Kubisnya Membusuk. Kompas. https://www.kompas.tv/article/103916/harga-kubis-anjlok-petani-di-jember-biarkan-tanaman-kubisnya-membusuk

Bramasta, Dandy Bayu. (2020). Melihat Virus Corona Menyerang Banyak Organ Tubuh Selain Paru-paru. Kompas.

Nirmala, A., N. Hanani, dan A. Muhaimin. (2016). Analisis faktor faktor yang mempengaruhi nilai tukar petani tanaman pangan di kabupaten jombang. Habitat. 27(2):66-71.

Nugroho, B. Y. H., S. Y. Wulandari, dan A. Ridlo. (2015). Analisis residu pestisida organofosfat di perairan mlonggo kabupaten jepara analysis of organophosphate pesticide residue in mlonggo waters, jepara. Jurnal Oseanografi. 4(3):541-544.

Nur, M. dan D. Priantinah. (2012). Analisis faktor-faktor yang mempengaruhi pengungkapan csr diindonesia (studi empiris pada perusahaan berkategori high profile yang listing di bei). Jurnal Nominal. I(I):1-13.

Nuzula, N. F. dan F. Nurlaily. (2020). Dasar-Dasar Manajemen Investasi. Universitas Brawijaya Press.

Pardiansyah, E. (2017). Investasi dalam perspektif ekonomi islam: pendekatan teoritis dan empiris. Economica: Jurnal Ekonomi Islam. 8(2):337-373.

Pramono, R. W. D. dan R. E. Suminar. (2019). Ekonomi Wilayah Untuk Perencanaan Tata Ruang. Deepublish.

Pratiwi, D., M. Ambayoen, dan A. Hardana. (2019). Studi pembiayaan mikro petani dalam pengambilan keputusan untuk kredit formal dan kredit nonformal. Habitat. 30(1):35-43.

Prayitno, A. B., Hasyim, A. I., \& Situmorang, S. (2013). Efisiensi Pemasaran Cabai Merah di Kecamatan Adiluwih Kabupaten Pringsewu Provinsi Lampung. Jurnal IImu Ilmu Agribisnis: Journal of Agribusiness Science, 1(1).

Purwaningsih, Y., S. Hartono, M. Masyhuri, dan J. H. Mulyo. (2015). Pola pengeluaran pangan rumah tangga menurut tingkat ketahanan pangan di provinsi jawa tengah. Jurnal Ekonomi Pembangunan: Kajian Masalah Ekonomi Dan Pembangunan. 11(2):236.

Rachmat, M. (2013). Nilai tukar petani : konsep, pengukuran dan relevansinya sebagai indikator kesejahteraan petani. Forum Penelitian Agro Ekonomi. 31(2):111.

Rimawati, R., T. Kurnia, dan A. Alhifni. (2019). Analysis of micro insurance models for fishermans (study in sukabumi and pangandaran port). Jurnal Ekonomi Dan Bisnis Islam (Journal of Islamic Economics and Business). 5(2):134.

Riyadh, M. I. (2015). Analisis nilai tukar petani komoditas tanaman pangan di sumatera utara. Jurnal Ekonomi Dan Kebijakan Publik. 6(1):17-32.

Rumagit, Desyani Panekenan ;Grace A. J. Rumangit, P. A. P. (2017). Peran kredit perbankan pada sektor pertanian di provinsi sulawesi utara. 13:183-194.

Saragih, J. R., F. Pertanian, dan U. Simalungun. (2016). Strategi pengembangan agribisnis hortikultura di wilayah pedesaan. 63-70.

SariAgri. (2020). Harga Kubis Anjlok Drastis, Petani di Magetan Menjerit. SariAgri. https:// 
sariagri.id/hortikultura/56846/harga-kubis-anjlok-drastis-petani-di-magetan menjerit

Sinaga, R. E. dan S. Tarigan. (2020). Perilaku petani dalam menghadapi fluktuasi harga usaha tani di tengah pandemi corona virus covid 19 di kabupaten dairi. Regionomic. 2(02):50-57.

Soetriono dan A. Suwandari. (2016). Pengantar ilmu pertanian agraris agribisnis industri. Digital Repository Universitas Jember. 27.

Sujai, M. (2016). Dampak kebijakan fiskal dalam upaya stabilisasi harga komoditas pertanian. Analisis Kebijakan Pertanian. 9(4):297.

Sunartomo, A. F. (2014). Strategi peningkatan kemampuan lembaga ekonomi pada kawasan hortikultura unggulan di kabupaten jember. JSEP : Jurnal Sosial Ekonomi Pertanian Vol 7 No 2 November 2014. 7(2):9-20.

Supanggih, D., \& Widodo, S. (2013). Aksesibilitas petani terhadap lembaga keuangan (studi kasus pada petani di desa sidodadi kecamatan Sukosewu kabupaten Bojonegoro). Agriekonomika, 2(2), 163-173.

Supriatna, A. (2008). Aksesibilitas petani kecil pada sumber kredit pertanian di tingkat desa: studi kasus petani padi di nusa tenggara barat. SOCA: Socioeconomics of Agriculture and Agribusiness. 8(2):0-15.

Susilowati SH. (2016). Fenomena penuaan petani dan berkurangnya tenaga kerja muda serta implikasinya bagi kebijakan pembangunan pertanian. Forum Penelit Agro Ekon 34(1):35 55. DOI: http://dx.doi.org/10.21082/fae.v34n1.2016.35-55.

Tenia Kurniawati, M. P. dan M. P. Andri Setiawan. (2020). Modul IImu Pengetahuan Sosial Edisi Pjj (Pembelajaran Jarak Jauh) Pada Masa Pandemi Covid-19 Untuk SMP Kelas VII. Ahlimedia Book.

Tjiptabudy, M. J. S. J. (2015). Kelembagaan Pertanian Dan Perikanan Dalam Rangka Ketahanan Pangan. Deepublish.

Todaro, Michael P. dan Smith, Stephen C. (2015). Economic development, edisi ke-12. Essex Pearson Education Limited. Harlow.

Utami, D. P., I. A. Wicaksono, D. Widiyantono, dan U. Hasanah. (2021). PENGUATAN kedaulatan pangan dan pendapatan masyarakat. 4:918-927.

Warto. (2015). Kondisi kemiskinan petani dan upaya penanggulangannya. Jurnal Penelitian Kesejahteraan Sosial. 14(1):20-29. 